\title{
Calongea, a new genus of truffles in the Pezizaceae (Pezizales)
}

\author{
by \\ Rosanne A. Healy ${ }^{1}$, Gregory Bonito ${ }^{2} \&$ James M. Trappe ${ }^{3}$ \\ ${ }^{1}$ Department of Plant Biology, University of Minnesota, 1445 Gortner Avenue, St. Paul, Minnesota 55108 USA. healy089@umn.edu \\ ${ }^{2}$ Department of Biology, Duke University, Durham, North Carolina 27708 USA. gmb2@duke.edu \\ ${ }^{3}$ Department of Forest Ecosystems and Society, Oregon State University, Corvallis, Oregon 97331-5752 USA. trappej@onid.orst.edu
}

\begin{abstract}
Healy, R.A., Bonito, G. \& Trappe, J.M. 2009. Calongea, a new genus of truffles in the Pezizaceae (Pezizales). Anales Jard. Bot. Madrid 66S1: 25-32.

Phylogenetic analysis of the ITS and LSU rDNA of Pachyphloeus species from Europe and North America revealed a new truffle genus. These molecular analyses plus sequences downloaded from a BLAST search in GenBank indicated that Pachyphloeus prieguensis is within the Pezizaceae but well outside of the genus Pachyphloeus. Morphological differences in the peridial and glebal hyphae and spores distinguish this genus from Pachyphloeus. We here propose the monotypic new genus Calongea, with the type species $C$. prieguensis comb. nov., in honor of Prof. Francisco de Diego Calonge, who has long studied the truffle fungi of Spain and participated in describing the type species of Calongea.
\end{abstract}

Keywords: Pachyphloeus, ITS, LSU, Ascomycota, molecular analysis, morphology, phylogeny.

\section{Introduction}

Pachyphloeus prieguensis Mor.-Arr., J. Gómez \& Calonge was described in 1996 from deciduous woodlands with calcareous soil in Spain (MorenoArroyo \& al., 1996). Some of its distinctive features include pallid, pink-tinged veins and labyrinthiform, mostly hollow canals within a tuberous, minutely verrucose, foul-smelling, dark reddish-brown to blackish-brown ascocarp. One challenge to identifying or describing truffles is that their relationships are confused by convergent morphologies. In their adaptation to a sequestrate habit, they gain features such as odors adapted for spore dispersal through mycophagy and lose features such as apothecia and forcible

\section{Resumen}

Healy, R.A., Bonito, G. \& Trappe, J.M. 2009. Calongea, un nuevo género de trufas en las Pezizaceae (Pezizales). Anales Jard. Bot. Madrid 66S1: 25-32 (en inglés).

El análisis filogenético del ITS y LSU rDNA de especies europeas y norteamericanas de Pachyphloeus revelan un género nuevo de trufa. Los datos moleculares de este estudio, además de las secuencias obtenidas de una búsqueda BLAST en GenBank, indican que Pachyphloeus prieguensis es un miembro de la familia Pezizaceae pero no está relacionado con ninguna otra especie hipogea o epigea de dicha familia. Encontramos diferencias morfológicas en las hifas del peridio y gleba así como en las esporas que morfológicamente distinguen éste de Pachyphloeus. Proponemos el nuevo género monotípico Calongea, con C. prieguensis comb. nov. como la especie tipo, en honor a uno de los descubridores originales, Prof. Francisco de Diego Calonge.

Palabras clave: Pachyphloeus, ITS, LSU, Ascomycota, datos moleculares, morfología, filogenia.

spore discharge adapted for aerial spore dispersal. Consequently, these sporocarps often resemble others in their ecological niche more than they resemble their most closely related epigeous relatives (Trappe \& Claridge, 2005; Læssøe \& Hansen, 2007).

During a phylogenetic study of Pachyphloeus species with use of ITS and LSU rDNA, P. prieguensis sequences consistently fell outside of the genus when analyzed with maximum parsimony and maximum likelihood optimization criteria. In addition, the ITS and LSU sequences of $P$. prieguensis were not very similar to any accessions held in Genbank's DNA sequence database $(82 \%$ and $93 \%$ similarity, respectively). These revelations prompted us to re-examine the morphology of $P$. prieguensis. In so doing, we 
found differences in the peridial structure, gleba and spore ornamentation that distinguish this taxon from Pachyphloeus.

\section{Materials and methods}

Dried pieces of ascocarps were rehydrated in 3\% $\mathrm{KOH}$ and either viewed with bright field microscopy or dehydrated in an ethanol series to $100 \%$, critical point dried in a DCP-1 Denton Critical Point Drying Apparatus (Denton Vacuum Inc., Cherry Hill, NJ), mounted on aluminum stubs with double-sided tape, silver painted around the specimen edges, sputtercoated for $120 \mathrm{sec}$ with $\mathrm{Au} / \mathrm{Pd}$, and visualized with $15 \mathrm{kV}$ in a JEOL 5800LV SEM. All images were digitally captured. Spore measurements were taken from 50 randomly selected spores, under $100 \times$ oil immersion.

Molecular analyses were done with DNA extracted from previously unexposed portions of mature gleba taken from the inside of air-dried ascocarps. DNA was extracted with 24:1 chloroform:isoamyl alcohol and precipitated in isopropanol. Both the internal transcribed spacer region (ITS1, 5.8S, and ITS2) and three divergent domains (D1, D2, D3) of the ribosomal large subunit (LSU) locus were amplified by use of the universal fungal primer set ITS5 - LR5 (Bertini \& al., 1999; Vilgalys \& Hester, 1990). PCR conditions and the handling of PCR products were as described in Healy \& al. (2009). Sanger sequencing was performed on an ABI3700 (Applied Biosystems, Foster City, CA) using Big Dye chemistry version 3.1 (Applied Biosystems, Foster City, CA) with the forward primer ITS5 and reverse primer LR5. DNA sequences were assembled and manually edited with Sequencher 4.0 (Gene Codes, Ann Arbor, MI) and queried against GenBank (http:// blast.ncbi. nlm.nih.gov/Blast.cgi) to compare with other sequences and to verify that sequences were of the target group. Sequences from top blast hits (LSU) were combined with our data and were aligned manually using Mesquite 4.0 (Maddison \& Maddison, 2002). Ambiguously aligned regions were excluded from the analyses. Phylogenetic analyses were conducted by the maximum parsimony and maximum likelihood methods. Parsimony analyses were carried out by a heuristic search in PAUP 4.0b10 with 1000 random addition sequences and 5000 bootstrap replicates (Swofford, 2001). Two independent maximum likelihood analyses based on a general-time-reversible 6parameter model of evolution were run using the software program GARLI and included 100 bootstrap replications (Zwickl, 2006). The truffle species Genea barknessii from within the Pyronemataceae was chosen as an outgroup based on previous studies focused on the systematics of the Pezizomycetes (Hansen \& Pfister, 2006). Sequences for Calongea prieguensis produced in this study were deposited in GenBank under accession numbers FJ228462 and FJ228463. Herbarium abbreviations are according to the Index Herbariorum (http://sweetgum.nybg.org/ ih/herbarium_list.php).

\section{Results of molecular analyses}

BLAST results of $C$. prieguensis sequences of the LSU (Table 1) and ITS/5.8S (Table 2) rDNA sequences had highest similarity ( $93 \%$ for LSU; $82 \%$ for ITS) to Genbank accessions of species in the Peziza depressa-Rublandiella clade of Læssøe \& Hansen, 2007.

Phylogenetic relationships of 27 ingroup Pezizaceae taxa based on maximum likelihood analyses of LSU rDNA are depicted in Figure 1. This most likely tree resulted from analyses that included 993 characters, of which 255 were parsimony-informative, 71 were variable but parsimony-uninformative (parsimony analysis) and 667 were constant. Bootstrap values for significantly supported nodes $(>70 \%)$ are labeled with parsimony bootstrap on top and likelihood bootstrap values below.

Table 1. Top BLAST results for Calongea prieguensis LSU rDNA.

\begin{tabular}{|l|c|c|c|c|c|}
\hline Taxonomic name & $\begin{array}{c}\text { Maximum } \\
\text { coverage }\end{array}$ & $\begin{array}{c}\text { Maximum } \\
\text { identity }\end{array}$ & $\begin{array}{c}\text { Alignment } \\
\text { scorea }\end{array}$ & $\begin{array}{c}\text { Genbank } \\
\text { ccession }\end{array}$ & E-value \\
\hline Peziza ellipsospora & $97 \%$ & $93 \%$ & 1299 & AF335139 & 0.00 \\
Peziza domiciliana & $97 \%$ & $92 \%$ & 1297 & AF335137 & 0.00 \\
Peziza badiofusca & $97 \%$ & $92 \%$ & 1297 & AF335132 & 0.00 \\
Peziza limnaea & $97 \%$ & $92 \%$ & 1291 & AF335147 & 0.00 \\
Peziza whitei & $97 \%$ & $92 \%$ & 1286 & AF335168 & 0.00 \\
Ruhlandiella berolinensis & $88 \%$ & $93 \%$ & 1179 & AF335175 & 0.00 \\
\hline
\end{tabular}


Table 2. Top BLAST results for Calongea prieguensis ITS/5.8S rDNA.

\begin{tabular}{|l|c|c|c|c|c|}
\hline Taxonomic name & $\begin{array}{c}\text { Maximum } \\
\text { coverage }\end{array}$ & $\begin{array}{c}\text { Maximum } \\
\text { identity }\end{array}$ & $\begin{array}{c}\text { Alignment } \\
\text { scorea }\end{array}$ & $\begin{array}{c}\text { Genbank } \\
\text { ccession }\end{array}$ & E-value \\
\hline Peziza depressa & $95 \%$ & $82 \%$ & 424 & EU819535 & $3 \mathrm{e}-115$ \\
Terfezia "trappei" & $95 \%$ & $81 \%$ & 412 & AF276676 & $6 \mathrm{e}-112$ \\
Terfezia leptoderma & $95 \%$ & $81 \%$ & 409 & AF396864 & $8 \mathrm{e}-111$ \\
Terfezia olbiensis & $95 \%$ & $81 \%$ & 407 & AF387657 & $3 \mathrm{e}-110$ \\
Terfezia claveryi & $100 \%$ & $81 \%$ & 401 & AF276671 & $1 \mathrm{e}-108$ \\
Tirmania nivea & $94 \%$ & $81 \%$ & 399 & AF276667 & $5 \mathrm{e}-108$ \\
\hline
\end{tabular}

\section{Taxonomic treatment}

Calongea Healy, Bonito \& Trappe, gen. nov. (Figs. 2-5)

A Pachyphloeo differt exipulo duplici; stratum exteriore pilis brevibus cellulis apicalibus versiformibus, bi in canalibus cavis similita praesentes; stratum interiore byphis filamentis et cellulis inflatis; canalibusque cavitatibus glebae epithecio peridioideo inclusis; sporae spinis variabiliter dispositis, frequenter curvis, sine perisporis; et ordinatione DNA ITS et LSU. Species typicus: Calongea prieguensis.

Differing from Pachyphloeus by its combination of a 2-layered peridium: outer layer of thick-walled cells giving rise to hairs with versiform tips; inner layer a mix of filamentous hyphae and inflated cells; a peridium-like epithecium with versiform hairs lining the canals and cavities; spores with spines of varying length, width and spacing, the spine bases connected by low ridges to form an irregular reticulum; and ITS and LSU DNA not congruent with other genera in the Pezizaceae.

Etymology: We dedicate this genus to Prof. Francisco de Diego Calonge, whose mycological career encompassed study of many groups, including truffle fungi, and who provided to J. Trappe hospitality, good fellowship, good stories, lessons on Spanish fungi, history, customs, culture, and outstanding food and wine, both in Madrid and on memorable field trips.

Calongea prieguensis (Mor.-Arr., J. Gómez \& Calonge) Healy, Bonito \& Trappe, comb. nov.

Basionym: Pachyphloeus prieguensis Mor.-Arr., J. Gómez \& Calonge, Bol. Soc. Micol. Madrid 21: 8788. 1996

Type: SPAIN. Córdoba, Priego, 4 April 1992 (MA).

Illustrations: Moreno-Arroyo \& al., Figs. 1-6 (1996); Montechi \& Sarasini, 210-211 (2000); Moreno-Arroyo \& al., 158-160 (2005).

GenBank Accession Numbers FJ228463, FJ 228462.
Ascomata 1-3 cm broad, subglobose to irregular. Peridium reddish brown in youth, by maturity blackish brown, nearly smooth or minutely verrucose. Gleba cream colored in youth, by maturity yellow to yellowish pink or light vinaceous, the context thick and containing elongated, labyrinthiform canals and chambers pallid in youth, by maturity pinkish to brown. Odor strong, most unpleasant, sweet-foetid; rehydrated herbarium specimens smell like rotting cardboard.

Peridium of two layers: outer layer 83-165 $\mu \mathrm{m}$ thick including the minute warts formed by mounded cells; cells in face view smoky-brown with golden-brown walls up to $7.4 \mu \mathrm{m}$ thick, isodiametric to subrectangular, length $\times$ width ca $40-41 \times 13 \mu \mathrm{m}$ to $50 \times 41 \mu \mathrm{m}$, interspersed with occasional large cells up to $100 \times 78$ $\mu \mathrm{m}$. Surface cells between the warts giving rise to unbranched, hyaline to smoky-brown hairs up to $60 \mu \mathrm{m}$ long, with one to several septa and walls $0.5-1.3 \mu \mathrm{m}$ thick; apical cells of the hairs globose to capitate, cylindrical or ventricose, $10-50 \mu \mathrm{m}$ long and 10-50 $\mu \mathrm{m}$ broad at the widest point (Fig. 2). The inner peridial layer is of hyaline, filamentous, interwoven cells up to $8.3 \mu \mathrm{m}$ broad and with walls $0.5 \mu \mathrm{m}$ thick interspersed with inflated cells up to $20 \mu \mathrm{m}$ broad with walls up to $3.3 \mu \mathrm{m}$ thick; this layer grades into the interwoven hyphae of the gleba. The peridium and outer glebal vein tissue together are 50-149 $\mu \mathrm{m}$ thick.

Gleba marbled with hollow canals lined with peridial-like tissue, subtended by veins of fertile tissue. The peridial-like tissue is composed of textura angularis, with large, thick-walled cells and superficial thinner-walled, septate hairs 60 to $100 \mu \mathrm{m}$ long (Figs. 3, 4 ), varying from filiform and $\pm 8 \mu \mathrm{m}$ broad at the septum with apical cells inflated up to $28 \mu \mathrm{m}$, and with the diversity of apical cells as on the peridial hairs.

Asci irregularly arranged in the fertile veins, oblong to pyriform, fresh measurements according to MorenoArroyo \& al. (1996) 65-125(140) × 30-50 $\mu \mathrm{m}$; not blueing (inamyloid) in Melzer's (iodine) solution, even after pre-treatment with $3 \% \mathrm{KOH}$, producing eight irregularly biseriate to inordinately arranged spores. Filamentous, interwoven to parallel hyphae among asci 5-8.3 


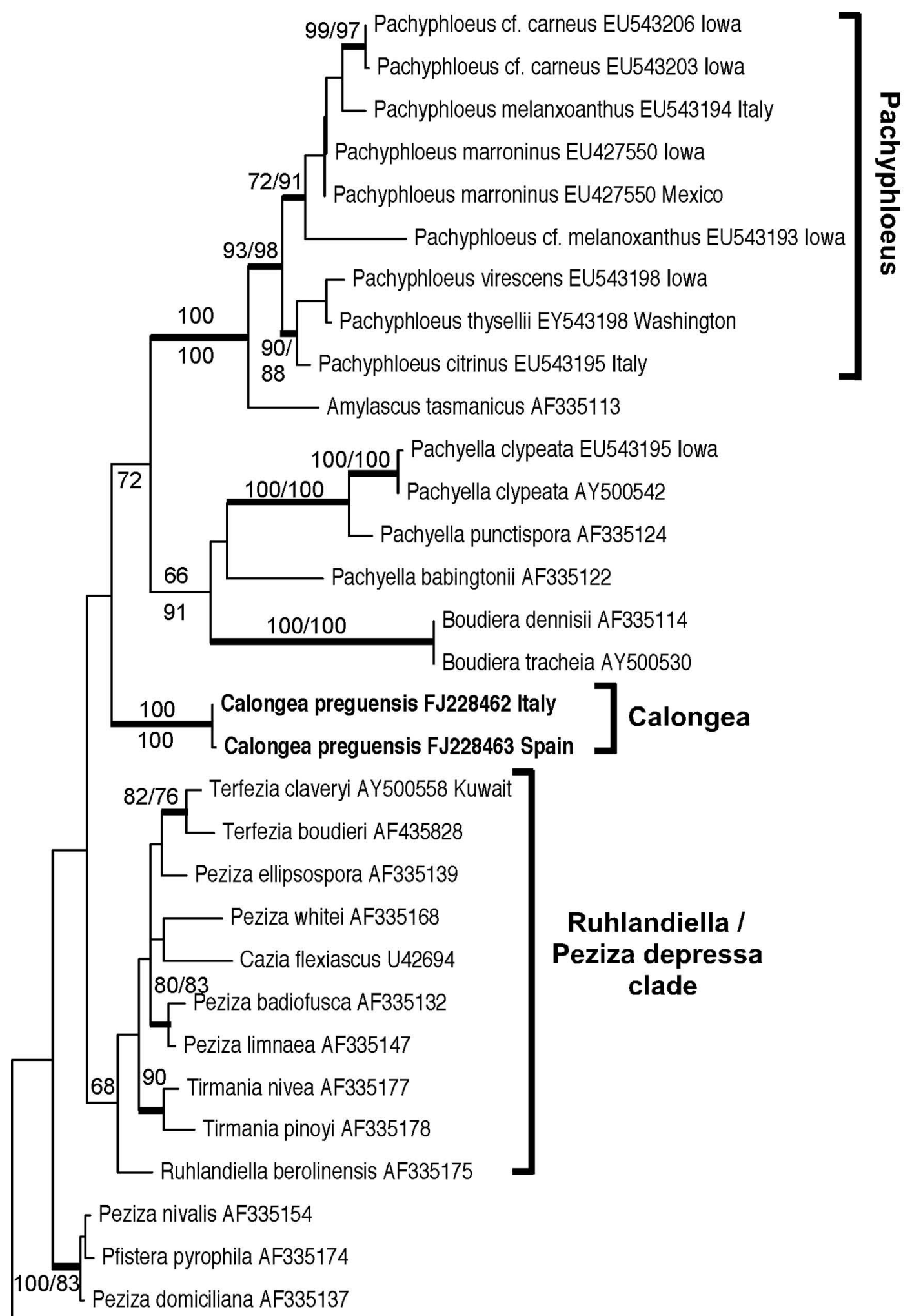

Genea harknessii DQ220334 Washington

- 0.01 substitutions/site

Fig. 1. Most likely tree from maximum likelihood analyses of LSU rDNA with 31 ingroup Pezizaceae. Bootstrap values for significantly supported nodes $(>70 \%)$ are thickened with parsimony bootstrap on top and likelihood values below. Taxon labels include the Latin binomial followed by the Genbank accession number and geographic origin (when known). Clades of focus in this paper have been labeled. 
$\mu \mathrm{m}$ in diameter, but inflated near the borders with peridial-like tissue. The glebal filaments merge with the peridial-like tissue and become indistinguishable from it. Interspersed among the narrow, filamentous hyphae and asci in the fertile veins are large-celled filamentous hyphae with cells swollen up to $58 \times 50 \mu \mathrm{m}$. These cells have hyaline to brown walls up to $2-5 \mu \mathrm{m}$ thick, and walls are thickest at the septae whereas cells they connect may be hyaline and thin-walled.

Spores globose, (16)17-19(22) $\mu \mathrm{m}$ (avg. $17.7 \mu \mathrm{m})$ including ornamentation, and (13)15-18(19.5) (avg. $15.6 \mu \mathrm{m})$ excluding ornamentation. Initially hyaline, at maturity the walls olivaceous brown and inamyloid, the ornamentation of flexuous spines, sometimes curved at the tips, varying in spacing on a given spore, and from 0.5-2.5 $\mu \mathrm{m}$ tall and 0.5-2 $\mu \mathrm{m}$ broad (Fig. 5); a low, irregular reticulum connects the bases of neighboring spines.

\section{Collections examined}

SPAIN. Córdoba: 15-IV-1990, J. Gómez, Trappe 12832, GenBank FJ228463 (OSC). ITALY. Laconi: 2-V-1999, Fantini 1980, GenBank FJ228462 (OSC).

Collections of Pachyphloeus species examined: ITALY. Venezia: Cuneo, Roascio, Pachyphloeus citrinus under mixed conifer and broadleaf forest, 12-IX-2000, M. Machioni JRWL2197, EU543196 (OSC); Pachyphloeus melanoxanthus under Ostrya and Quercus, I1999, Macchioni 1860, EU543194 (OSC); MEXICO. Nuevo Leon: Santiago, El Ranchito, Pachyphloeus marroninus under Quercus polymorpha, 14-IX-1983, García 3757, EU427551 (UNL). UNITED STATES. Iowa: Story County, Ames, YMCA Woods, Pachyphloeus of carneus under Quercus macrocarpa, 9-VIII-2000, Healy 756, EU543206 (ISC). Story County, Hickory Grove Park, Pachyphloeus cf melanoxanthus under Quercus alba, Tilia americana, Carya ovata, 28-VII-2000, Healy 735, EU543193 (ISC); Winneshiek County, Upper Iowa Public Fishing Access, Pachyphloeus marroninus under Quercus alba and Q. macrocarpa, 2-X-1998, Healy 286, EU427550 (ISC, OSC); Woodbury County, Stone State Park, Pachyphloeus cf carneus under Quercus macrocarpa, 8VIII-1999, Healy 525, EU543203 (ISC). Woodbury County, Stone State Park, Pachyphloeus virescens, 27-VII-2000, Healy 729, EU543198 (ISC); Washington: Thurston County, Fort Lewis, Pachyphloeus thysellii under Pseudotsuga menziesii, 18-VIII-1993, Trappe 13082, EU543197 (OSC).

Also examined: UNITED STATES. Iowa: Webster County, Woodman Hollow State Preserve, Pachyella clypeata on log in riparian area in deciduous woods, 18-IX-2005, Healy, EU543195 (ISC).

\section{Calongea prieguensis and Pachyphloeus species compared}

The genus Pachyphloeus was described in 1844, typified by P. melanoxanthus (Tul.) Tul. \& C. Tul., with the following characteristics: 1.) a thick, fleshy peridium with small warts; 2 .) a thick-margined orifice stuffed with hyphae, where the interstitial veins come to the surface at the apex of the ascocarp and separate into fissures; 3.) a narrow point of attachment; 4.) sterile veins that marble the gleba, and initially differ in color from the fertile tissue but later the color becomes more uniform overall; and 5.) a wellordered series of asci with eight globose spores ornamented with spines, irregularly arranged in the ascus, colored at maturity (Tul. \& Tul., 1844).

Since the original description of Pachyphloeus, it has become evident that another feature that unifies this genus is a single-layered peridium of thick-walled textura angularis (Pegler \& al., 1993; Montecchi \& Sarasini, 2000; Hansen \& al., 2001; Healy, 2002). In contrast, $C$. prieguensis has a duplex peridium composed of a mixture of textura globulosa and textura angularis in the outer layer, subtended by a mixture of interwoven filamentous and inflated hypae. The erecting of a new genus to accommodate Calongea prieguensis unifies the type of peridium present on species of Pachyphloeus.

Unlike Pachyphloeus, the peridium of $C$. prieguensis has short hairs with apical cells of variable shapes and diameters, distinct from their subtending cells. These are also present on the cells lining the hollow (rather then stuffed) canals. The peculiar hairs on the excipulum of Calongea have not been reported in Pachyphloeus. Some Pachyphloeus, such as P. conglomeratus, $P$. lateritius and $P$. austro-oregonensis have slender; hyphoid hairs of uniform diameter on the peridium (Berk. \& Broome, 1846; Fogel \& States, 2002; Frank \& al., 2006, respectively), and many species have a basal mycelial tuft. Calongea lacks a basal mycelial tuft.

Asci of many Pachyphloeus species are arranged in a well ordered to irregular palisade with paraphyses. The canals between opposing hymenia are stuffed with extensions of these paraphyses, and the sterile veins are composed of textura angularis similar to cells of the peridium. In contrast, Calongea asci are irregularly arranged in the gleba, and canals are open, not stuffed. In addition, the large-celled, brownwalled filamentous hyphae in the fertile tissue of $\mathrm{Ca}$ longea have not been reported from any species of Pachyphloeus. The asci of P. conglomeratus are disorganized in the gleba, but unlike Calongea, this species has a solid gleba. Pachyphloeus austro-oregonensis has empty canals between opposing hymenia, and in places where the excipulum invaginates the gleba (Frank \& al., 2006). However, Calongea canals are very different, in that they are lined by excipular-like rather than hymenial tissue.

The ornamentation of Pachyphloeus spores is of rigid, straight (not curved) short to long, often capitate spines evenly distributed on the spores. Spines on 


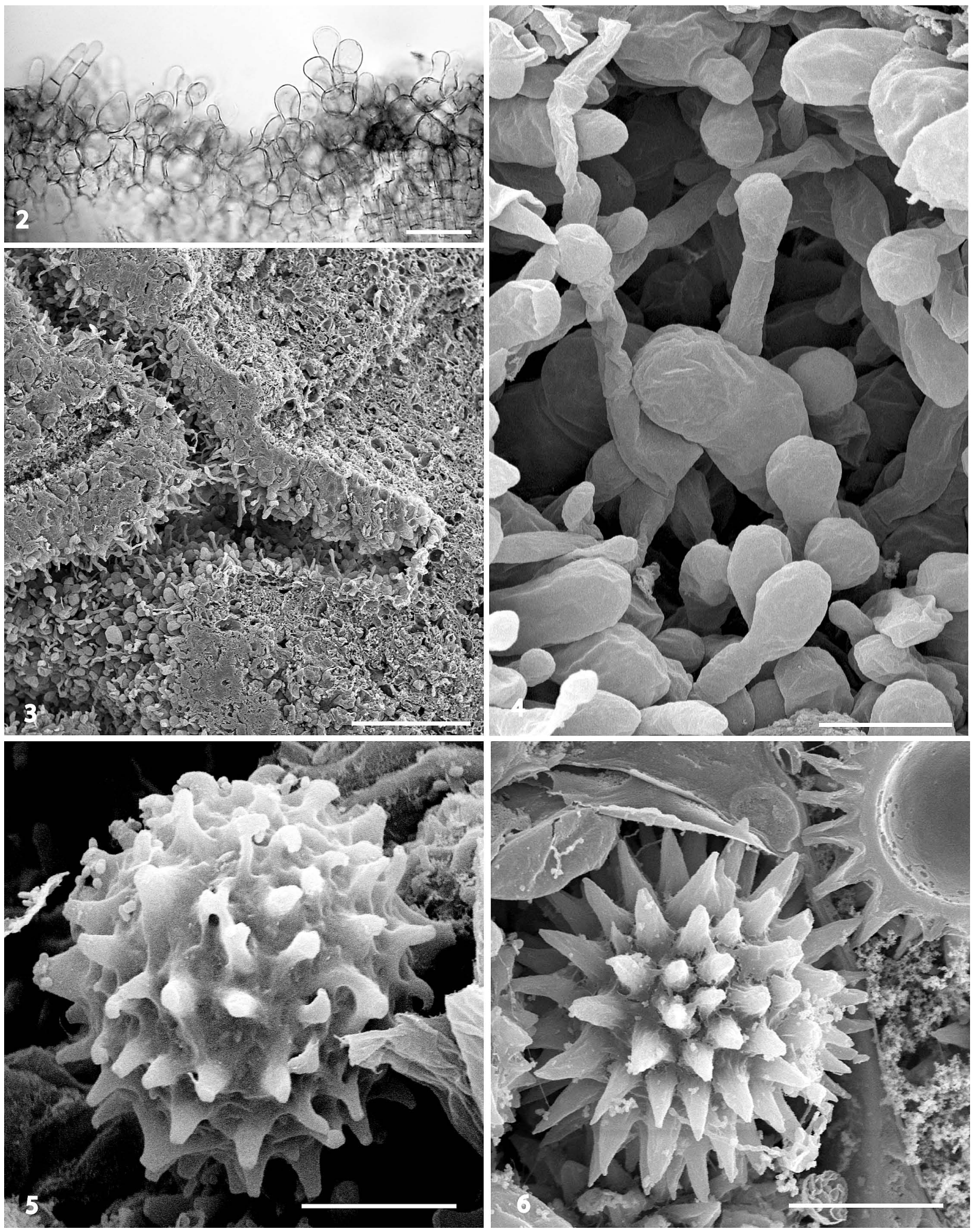

Fig. 2. Bright field microscopy, Calongea prieguensis excipular hairs. Scale bar $=50 \mu \mathrm{m}$. Figs. 3-6. Scanning electron micrographs. Fig. 3. Hollow glebal canal lined with hairs in C. prieguensis. Scale bar $=250 \mu \mathrm{m}$. Fig. 4. Higher magnification of Fig. 3 showing details of hairs along the glebal canals. Scale bar $=25 \mu \mathrm{m}$. Fig. 5. Spore of $C$. prieguensis. Scale bar $=10 \mu \mathrm{m}$. Fig. $\mathbf{6}$. Spore of an undescribed, North American Pachyphloeus species. Scale bar $=5 \mu \mathrm{m}$. 
any given spore are uniform in length. Spine development appears to be the same among species of Pachyphloeus, until nearly mature, when variations occur. The spine apices may coalesce to partially or fully cover the spores in some species, forming the perisporium (Healy, 2002). The distribution, height, and width of spore spines of Calongea are irregular, and the spines themselves are often curved rather than straight. No evidence was seen of a perisporium. Pachyphloeus spores most similar to C. prieguensis are of an undescribed species from North America that also lacks a perispore, and has straight rather then the more usual capitate spines of other Pachyphloeus species (Fig. 6). However, unlike Calongea, and in keeping with other Pachyphloeus, the spines are rigid, and uniform in length, diameter, and distribution.

A recent effort to delimit the Pezizaceae, on the basis of parsimony analyses of LSU rDNA or on the basis of morphological similarity (Mycoclelandia and Sphaerozone), included the following fourteen truffle or truffle-like genera in the family: Amylascus, Cazia, Eremiomyces, Hydnobolites, Hydnotryopsis, Kalaharituber, Mattirolomyces, Mycoclelandia, Pachyphloeus, sequestrate Peziza (P. whitei and P. ellipsospora), Ruhlandiella, Sphaerozone, Terfezia and Tirmania (Læssøe \& Hansen, 2007). These authors defined ascomycetous truffles as ascocarps produced at or below ground level that lack forcible spore discharge. Here, we refer to genera as "truffle-like" if they fit this definition, but retain forcible spore-discharge (are operculate), and/or lack a peridial covering. Our results, based on both molecular and morphological characters, yielded the discovery of yet another truffle lineage in the Pezizaceae and add to our knowledge of truffle biodiversity. The proposed new genus $\mathrm{Ca}$ longea brings the number of truffles and truffle-like genera in this family to fifteen.

\section{A comparison of Calongea to other genera in the Pezizaceae}

BLAST results of ITS and LSU sequences from $\mathrm{Ca}$ longea prieguensis have highest affinity to taxa in the Peziza depressa-Rublandiella clade of the most recent circumscription of the Pezizaceae. Our phylogenetic analyses also place Calongea close to (but outside of) this clade. The Peziza depressa-Rublandiella clade includes apothecial species with asci that are blue over the entire length in iodine solutions (amyloid), rather than at the apex only (Hansen \& al., 2001; Hansen \& al., 2005; Læssøe \& Hansen, 2007). It also includes truffle-like genera that lack a peridium, and instead have an epithecial covering of the hymenium, and weakly amyloid, indehiscent asci (Rublandiella,
Sphaerozone in Dissing and Korf, 1980), truffle-like species that have a distinct peridium, and amyloid, operculate asci (Peziza ellipsospora, P. whitei in Trappe, 1979), truffles that have a peridium, and amyloid, indehiscent asci (Tirmania in Trappe, 1971), and truffles that have a peridium, with inamyloid, indehiscent asci (Terfezia in Trappe, 1971; Cazia in Trappe 1989). In these features, C. prieguensis is most similar to Terfezia and Cazia. We agree with previous authors who have observed that operculate and amyloid asci, features traditionally used to delimit the Pezizaceae (Kimbrough, 1970; Korf, 1973), may not be useful for placing the truffles and truffle-like taxa into families (eg. Díez \& al., 2002; Læssøe \& Hansen, 2007; Trappe, 1979). Calongea is an additional truffle in which these delimiting features are lacking, and for which there is morphological and molecular support for placement in the Pezizaceae

Some additional comparisons between Calongea and other truffle-like genera in the Peziza depressaRublandiella clade are listed here. Rublandiella has paraphyses and epithecia that are gelatinous, and the spores are alveolate-reticulate (Dissing \& Korf, 2000). The duplex structure of the peridium of Calongea is similar to Peziza, but Peziza spores are ellipsoidal in shape. Like Calongea, the peridium of Cazia has occasional large cells, but the peridium is glabrous, the gleba is solid, and the spores are ellipsoidal. Among other genera with globose spores, Terfezia and Tirmania have a similar tissue type in their peridia, but have a solid gleba, rather than hollow canals. Spore ornamentation resembles that of Terfezia leptoderma and T. olbiensis in variation of spine width, and distribution, and the wartiness along the spore wall surface between spines (see electron micrographs in Montecchi \& Sarasini, 2000), which we interpret as incipient spines on Calongea spores.

Previous studies based on LSU rDNA have not resolved the higher order relationships among the major clades within the Pezizaceae (Hansen \& Pfister, 2006; Læssøe \& Hansen, 2007). Our results demonstrate a similar lack of resolution with this locus. Although we can say with confidence that Calongea and Pachyphloeus are distinct from each other, and that $\mathrm{Ca}$ longea appears close to species in the Peziza depressaRublandiella clade, we have not been able to determine the closest apothecial, truffle, or truffle-like relative of Calongea. The use of more genetic markers (e.g. RNA polymerase I \& II), the discovery of new taxa, and greater taxon sampling could help resolve the relationships between Calongea and other genera within the Pezizaceae. 


\section{Acknowledgements}

The authors thank two anonymous reviewers for their thoughtful and helpful suggestions that improved this manuscript, and Efren Cázares for translation of the abstract. Healy thanks Dr. HT Horner and staff at the Nanotechnology, Imaging and Microscopy Facility at Iowa State University for use of their equipment for the SEM portion of this project. The authors thank Dr. Rytas Vilgalys for consultation and for generously sharing his lab and equipment to do molecular analysis. Trappe's participation in the study was supported by the USDA, Forest Service, and Pacific Northwest Research Station. The herbarium at Kew is thanked for loan of type material of Pachyphloeus. The following herbaria are thanked for accessioning voucher specimens: Iowa State University Botany Department (ISC), Oregon State University Department of Botany and Plant Pathology (OSC), and Universidad Autónoma de Nuevo León, Facultad de Ciencias Biológicas (UNL).

\section{References}

Berkeley, M.J. \& Broome, E.C. 1846. Notices of British Hypogeous Fungi. The Annals and Magazine of Natural History 18: 73-82.

Berkeley, M.J. \& Broome, E.C. 1967 (Reprint). Notices of British Fungi. Bibliotheca Mycologica. Verlag von J. Cramer. N.Y.

Bertini, L., Amicucci, A., Agostini, D., Polidori, E., Potenza, L., Guidi, C. \& Stocchi, V. 1999. A new pair of primers designed for amplification of the ITS region in Tuber species. FEMS Microbiology Letters 173: 239-245.

Calonge, F.D., García, F. \& Juste, P. 2002. Nuovi dati sui funghi ipogei della Spagna. IX. Pachyphloeus macrosporus sp. nov. Bollettino Gruppo Mycologico G. Bresadola 45: 51-61.

Díez, J., Manjón, J.L. \& Martin, F. 2002. Molecular phylogeny of the mycorrhizal desert truffles (Terfezia and Tirmania), host specificity and edaphic tolerance. Mycologia 94: 247-259.

Dissing, H. \& Korf, R.P. 1980. Preliminary studies in the genera Ruhlandiella, Sphaerosoma, and Sphaerozone (order Pezizales). Mycotaxon 12: 287-306

Eckblad, F.E. 1968. The genera of the operculate Discomycetes. A re-evaluation of their taxonomy, phylogeny and nomenclature. Nytt Magasin for Botanike 15: 1-191.

Fogel, R. \& States, J. 2002. Materials for a hypogeous mycoflora of the great basin and adjacent cordilleras of the western United States. VIII: Pachyphloeus lateritius sp. nov. and Cazia quericola sp. nov. (Ascomycota, Pezizales). Mycotaxon 81: 83-89.

Frank, J.L., Southworth, D. \& Trappe J.M. 2006. NATS truffle and truffle-like fungi 14: Pachyphloeus austro-oregonensis, a new species from southern Oregon. Mycotaxon 98: 253-259.

Hansen, K. \& Pfister D.H. 2006. Systematics of the Pezizomycetes - the operculate discomycetes. Mycologia. 98: 1029-1040.

Hansen, K., Læssøe, T. \& Pfister, D.H. 2001. Phylogenetics of the Pezizaceae, with an emphasis on Peziza. Mycologia 93: 958-990.

Hansen, K., LoBuglio, K.F. \& Pfister, D.H. 2005. Evolutionary relationships of the cup-fungus genus Peziza and Pezizaceae inferred from multiple nuclear genes: RPB2, ß-tubulin, and LSU rDNA. Molecular Phylogenetics and Evolution 36: 1-23.
Healy, R.A. 2002. Spore wall development and septal pore ultrastructure in three species of Pachyphloeus. M.S. thesis. Department of Botany, Iowa State University. Ames.

Healy, R.A., Bonito, G. \& Guevara, G. 2009. The truffle genus Pachyphloeus in the U.S. and Mexico: phylogenetic analysis and a new species. Mycotaxon 107: 61-71.

Kimbrough, J.W. 1970. Current trends in the classification of discomycetes. Botanical Review 36: 91-161.

Korf, R.P. 1973. Discomycetes and Tuberales. In: Ainsworth, G.C., Sparrow, F.K. \& Sussman, A.S. (eds.), The Fungi IVA. Academic Press, New York. Pp. 249-319.

Læssøe, T. \& Hansen, K. 2007. Truffle trouble: what happened to the Tuberales? Mycological Research 111: 1075-1099.

Maddison, D. \& Maddison W. 2002. MacClade: Analysis of Phylogeny and Character Evolution. version 4.0. Sinauer Associates. Sunderland.

Montecchi, A. \& Sarasini, M. 2000. Funghi Ipogei d'Europa. Associazione Micologica Bresadola. Trento.

Moreno-Arroyo, B., Gómez, J. \& Calonge, F.D. 1996. Pachyphloeus prieguensis, sp. nov. (Ascomycotina), encontrada en España. Boletín de la Sociedad Micológica de Madrid 21: 85-92.

Moreno-Arroyo, B., Gómez, Fernández, J. \& Pulido Calmaestra, E. 2005. Tesoros de Nuestros Montes. Trufas de Andalucía. Consejería de Medio Ambiente, Junta de Andalucía, Córdoba.

Pegler, D.N., Spooner, B.M. \& Young, T.W.K. 1993. British Truffles A Revision of British Hypogeous Fungi. Royal Botanic Gardens, Kew.

Swofford, D. 2001. PAUP*. Phylogenetic Analysis Using Parsimony ("and Other Methods). Version 4. Sinauer Associates. Sunderland.

Trappe, J.M. 1971. A synopsis of the Carbomycetaceae and Terfeziaceae (Tuberales). Transactions of the British Mycological Society 57: 85-92.

Trappe, J.M. 1979. The orders, families, and genera of hypogeous ascomycotina (truffles and their relatives). Mycotaxon 9: 297340.

Trappe, J.M. 1989. Cazia flexiascus gen. et sp. nov., a hypogeous fungus in the Helvellaceae. Memoirs of the New York Botanical Garden 49: 336-338.

Trappe, J.M. \& Claridge, A.W. 2005. Hypogeous fungi: evolution of reproductive and dispersal strategies through interactions with animals and mycorrhizal plants. In: Dighton, J. \& al. (eds.), The Fungal Community - Its Organization and Role in the Ecosystem. 3rd Ed. p. 613-623. Taylor \& Francis. Boca Raton.

Tulasne, L.R. \& Tulasne, C. 1844. Fungi hypogaei nonnulli, novi vel minus cogniti. Giornale Botanico Italiano Anno I, part I. 2: 55-63.

Vilgalys, R. \& Hester, M. 1990. Rapid genetic identification and mapping of enzymatically amplified ribosomal DNA from several species of Cryptococcus. Journal of Bacteriology 172: 42384246.

Zwickl, D. 2006. Genetic algorithm approaches for the phylogenetic analysis of large biological sequence datasets under the maximum likelihood criterion. Ph.D. dissertation. University of Texas. Austin.

Received: 13-XI-2008

Accepted: 16-I-2009 